\title{
Prey envenomation does not improve digestive performance in Taiwanese pit vipers (Trimeresurus gracilis and T. stejnegeri stejnegeri)
}

\author{
Chia-Wei Chu ${ }^{\text {a }}$, Tein-Shun Tsai ${ }^{b}$, Inn-Ho Tsai ${ }^{c}$, Yao-Sung Lin ${ }^{a}$, Ming-Chung Tu ${ }^{\text {b,* }}$ \\ a Department of Life Science, National Taiwan University, Taipei, Taiwan \\ b Department of Life Science, National Taiwan Normal University, Taipei, Taiwan \\ c Institute of Biological chemistry, Academia Sinica; Graduate Institute of Biochemical Sciences, National Taiwan University, Taipei, Taiwan
}

\section{A R T I C L E I N F O}

\section{Article history:}

Received 20 October 2008

Received in revised form 9 January 2009

Accepted 12 January 2009

Available online 20 January 2009

\section{Keywords:}

Digestive efficiency

SDA

Passage time

Cold adaptation

Asian pit vipers

\begin{abstract}
A B S T R A C T
It has been a common belief that snake venom may help in the digestion of its prey, although direct examples and supporting evidence have not been sufficient. To address this, the present study examined whether preinjecting natural amounts of pit viper venom into experimental mice may accelerate their digestion by the snakes or gain energy benefit as compared to the control without the envenomation. Live adults of two Asian pit viper species Trimeresurus gracilis and T. stejnegeri stejnegeri, which inhabit the cold and warm environment respectively, were the subjects studied herein. A natural dose of $1.2 \mathrm{mg}$ of each of the pit viper venom in phosphate-buffered saline (PBS) was injected into the mouse (about $10 \%$ of the snake mass) before it was being fed to the same species of vipers, while the pit vipers in control group were given mouse injected with sterile PBS. The snakes were kept at $14{ }^{\circ} \mathrm{C}$ or $24{ }^{\circ} \mathrm{C}$, and parameters of gut passage time, costs of digestion, and/or digestive efficiency were measured. The results did not support the hypotheses that envenomation facilitates prey digestion. The venom in fact caused longer first defecation time and lower assimilation energy at $14{ }^{\circ} \mathrm{C}$. Besides, the time to reach the oxygen consumption peak, and the first defecation time of $T$. s. stejnegeri were longer than that of $T$. gracilis.
\end{abstract}

Crown Copyright @ 2009 Published by Elsevier Inc. All rights reserved.

\section{Introduction}

Snake venom is a complex mixture of proteins, enzymes, and other organic compounds. Snake venom proteins are originated from recruitment of snake body proteins (Fry and Wuster, 2004; Fry, 2005). The venom glands have been evolved as an exocrine system specializing in prey capture (Fry et al., 2006). Accelerated evolution including gene duplication and fast mutations in the protein coding sequences resulted in the great diversity of venoms (Deshimaru et al., 1996; Fry and Wuster, 2004). Snake venom has evolved to adapt to the prey ecology and to cope with the rather diverse molecular targets in the prey (Daltry et al., 1997). Pit viper venom contains various hydrolases or digestive enzymes, including metalloproteinases (Tsai et al., 2000; Gutierrez et al., 2005), serine proteases (Deshimaru et al., 1996; Wang et al., 2001), phospholipases $A_{2}$ (Kini, 2003), hyaluronidase (Harrison et al., 2007), phosphomonoesterases, and phosphodiesterases (Valerio et al., 2002). These venom enzymes play the role of neurotoxin, myotoxin, anticoagulant, hypertensive or spreading agents (Aird, 2002), and some of them have undergone mutations to lose their catalytic activities (Li et al., 2005b; Tsai, 2006). Some venom proteins also play the role of antibacterial agents (Tsai et al., 2007).

\footnotetext{
* Corresponding author. Tel.: +8862 29333149x321; fax: +886229312904. E-mail address: biofv026@ntnu.edu.tw (M.-C. Tu).
}

Although the toxicities and applications of snake venom have been recognized throughout history, the adaptive significance of these powerful mixtures on predatory, defensive, and/or digestive functions remains to be explored. The 'digestive hypothesis' for snake venom suggests that the venom's proteolytic activities function to increase the performance on digestion factors such as gastric digestion time, gut passage time, costs of digestion, or digestive efficiency (McCue, 2007). A limited number of studies have examined the digestion hypothesis. When viperid snakes (Bothrops jararacussu and Vipera aspis) were prevented from envenomating the prey or fed on a dead prey, they experienced longer gut passage time than normal (cited in Thomas and Pough, 1979). It was also reported that when the venom of Western Diamondback (Crotalus atrox) was injected into live mice before they were swallowed by non-venomous snakes, the digestion process became faster, and such effect of venom was more pronounced when digestion was tested at $15{ }^{\circ} \mathrm{C}$ than at $25^{\circ} \mathrm{C}$ (Thomas and Pough, 1979). Nicholson et al. (2006) studied the in vitro digestive effect of Coastal Taipan (Oxyuranus scutellatus) venom on mice hind legs under an acidic digestive environment and proposed that the venom might contribute to digestion of the prey.

An increase in metabolism caused by the ingestion of food is called specific dynamic action (SDA), which is believed to be a sum of energy required for muscle activity (peristalsis), secretary processes, protein catabolism, active transport (nutrient uptake), protein synthesis, and nitrogenous waste excretion (McCue and Lillywhite, 2002; Secor, 
2003). It has been found that feeding pre-cooked and/or ground and pepsin-digested food elicited less SDA in pythons or rats (Gawęcki and Jeszka, 1979; Boback et al., 2007). However, Mendes and Abe (1999) have suggested that the venom of South American rattlers ( $C$. durissus) may not have digestive functions based on the SDA data. A recent study (McCue, 2007) also revealed that envenomation had no significant influence on any of the measured digestive performance variables, including the gut passage rate, costs of digestion (SDA), and digestive efficiency. Whether the venom may facilitate the digestion of prey by venomous snakes thus remains controversial and should be re-examined. For example, it may be argued that the digestion temperature of $30{ }^{\circ} \mathrm{C}$ in the above two studies might be too high to detect any significant influence of envenomation on digestive performance (McCue, 2007). Thus, one aim of the present study is to test or confirm these findings by investigating the effects of prey envenomation on the digestive performance of Asian pit vipers below $30{ }^{\circ} \mathrm{C}$.

The digestive function in reptiles is temperature sensitive, which may be a great problem, especially at low temperatures, for some infrequent-feeding snakes because they ingest large prey and swallow the whole prey without mastication (Thomas and Pough, 1979). In a previous study (Tsai et al., 2008), we investigated the effects of temperature and meal size on SDA-associated factors, apparent assimilation efficiency, and digestive rate in Chinese green tree vipers, Trimeresurus s. stejnegeri Schmidt, 1925. We also reviewed the SDAassociated factors in terrestrial snakes including pit vipers, and compared them with arboreal T. s. stejnegeri. However, the digestive effects of venom on Asian pit vipers under different temperatures had not been studied. T. s. stejnegeri mostly inhabit low-elevation areas, whereas the endemic Taiwanese mountainous pit viper, T. gracilis Oshima, 1920, is inhabiting at altitudes above $2000 \mathrm{~m}$ (Lue et al., 1999; Huang et al., 2007). It has been proposed that envenomation might help pit vipers to digest large prey at cooler temperatures (Thomas and Pough, 1979; chapter 4 in Greene, 1997). Thus, another aim of this study is to test if envenomation may improve the gut passage rate, costs of digestion, and digestive efficiency more significantly at lower temperatures, especially in the cold-adapted $T$. gracilis.

\section{Materials and methods}

\subsection{Snakes and venom}

Animal collection has been approved by Council of Agriculture, Executive Yun, Taiwan (approval number: 0931605110). Healthy adult T. gracilis were collected from mountain areas $2000 \mathrm{~m}$ above sea level in central and southern Taiwan, and healthy adult T. s. stejnegeri were collected from lowland areas in northern and western Taiwan. Venoms of $25 \mathrm{~T}$. gracilis (mean $\pm \mathrm{SE}$ of body mass $=48 \pm 6 \mathrm{~g}$ ) and $19 \mathrm{~T}$. $\mathrm{s}$. stejnegeri (body mass $=55 \pm 4 \mathrm{~g}$ ) were collected separately and protein concentration of each venom was determined, after the volume and the weight were recorded. Protein concentration of the pooled venom was determined by the method of Bradford (1976). The average amount (mean \pm SE) of venom extracted from each individual was found to be $3.12 \pm 0.45 \mathrm{mg}$ and $4.07 \pm 0.86 \mathrm{mg}$ for T. gracilis and $T$. $s$. stejnegeri, respectively. The samples were then pooled together and lyophilized before use.

A total of 14 adult T. s. stejnegeri (range 40.0-131.5 g) were tested to investigate the amount of venom injected on predation. Based on the method of Hayes et al. (1992) with minor modifications, we measured the amount of venom injected in each mouse (ICR; 4.2-9.2 g) using ELISA and specific antivenoms provided by Dr. Liau, M.-Y. (The Vaccine Unit, Center of Preventive Medicine, Taiwan). We found that $T$. $s$. stejnegeri snakebite injected an average of $1.22 \mathrm{mg}$ of venom proteins. This is also consistent with previously observations (Liau and Huang, 1997). We did not determine the average amount of $T$. gracilis envenomating due to the lack of its specific antivenom. The amount of venom proteins injected into each mouse in our experiments was set as $1.20 \mathrm{mg}$ for both species.

\subsection{Feeding trials}

The feeding trials were conducted from November 2002 to February 2003. The pit vipers were kept in individual translucent plastic containers of $28 \times 18 \times 17 \mathrm{~cm}$ and given an illumination cycle of $12 \mathrm{~h}$ light and $12 \mathrm{~h}$ dark, with the lights turned off at $1730 \mathrm{~h}$ and turned on at $0530 \mathrm{~h}$, in an animal room at $24^{\circ} \mathrm{C}$. The bottom of the container was equipped with foil (Greenwald and Kanter, 1979; Tsai et al., 2008) to make collection/analyses of the droppings easier. The snakes were fed once every two weeks before the experiments started and water was given all the time. One group of snakes (group I: seven T. gracilis and eight T. s. stejnegeri) was acclimated at $14{ }^{\circ} \mathrm{C}$ for 10 days while the other (group II: eight $T$. gracilis and eight $T$. s. stejnegeri) remained at $24{ }^{\circ} \mathrm{C}$. The digestion experiments of both groups were carried out at 14 and $24^{\circ} \mathrm{C}$, respectively.

For each group, the snakes of each species were randomly divided into two subgroups: the experimental and the control subgroups, and were fed with mice ( $10 \pm 1 \%$ of snake body mass). Before feeding, the mice in the experimental subgroup were injected with a lethal dose of venom (1.20 mg in $100 \mu \mathrm{L}$ phosphate-buffered saline or PBS), while those in the control subgroup were injected with $100 \mu \mathrm{L}$ PBS only and killed by cervical dislocation. We inserted three blue plastic beads (diameter $=1.0$ to $1.6 \mathrm{~mm}$ ) into the mouth and three red plastic beads into the anus in each dead mouse. The dead mouse was then force-fed to the snakes, whose fangs were previously clipped with a tiny plastic clip $(2.5 \times 3 \mathrm{~cm})$ to avoid their stretching out and injecting venom. By gently clipping at the upper jaw, the fangs were fixed, and no harmful events were noticed in the clipping procedure. The snakes could normally and actively feed thereafter. In addition, the feeding trials in group I were repeated as the snakes originally in the experimental subgroup were shifted to the control subgroup, and vice versa.

\subsection{Passage time and digestive efficiency}

Passage time was judged by two indicators: first defecation time, which was the time when the first fecal mass containing blue plastic beads appeared, and the final defecation time, which was the time when the final fecal mass containing red beads appeared. We collected the fecal masses until all plastic beads were voided (up to 35 days), and the energy of fecal masses was determined after being stored at $-20{ }^{\circ} \mathrm{C}$ and freeze-dried to constant mass. Unfortunately, the fecal mass data of group II were incomplete, and were discarded. We used a semi-micro bomb calorimeter (model 1425, Parr Instrument Inc., Moline, IL, USA) to determine the energy content of fecal samples. Prior to the measurement, feces and urine pellets were separately ground to fine consistency with mortar and pestle. The feces and urine were then pressed into pellets, weighed and assayed in the bomb calorimeter. Similarly, the energy of 10 non-digested mice (body mass $=3.0$ to $7.6 \mathrm{~g}$ ) was measured to correlate the energy (J) to wet mass $(\mathrm{g})$ of mouse. The relationship was mouse energy $=-15238.8+$ $10477.7 \times$ mouse mass $\left(r^{2}=0.992, P<0.0001\right)$. Apparent digestive and assimilation efficiencies were determined by the following formulae (Bedford and Christian, 2000; McConnachie and Alexander, 2004; Cox and Secor, 2007):

Apparent digestive energy = total energy consumption - energy lost in feces

Apparent digestive efficiency= apparent digestive energy / total energy consumption

Apparent assimilation energy = total energy consumption - energy lost in feces and uric acid

Apparent assimilation efficiency=apparent assimilation energy / total energy consumption. 


\subsection{Measurements of SDA associated factors}

Oxygen consumption rates $\left(V_{\mathrm{O} 2}\right)$ before and during digestion were measured with a Qubit respiration package (Qubit Systems Inc., Kingston, ON, Canada). Sensitivity of the oxygen analyzer was $100 \mathrm{ppm}$, and $V_{\mathrm{O} 2}$ was measured in a modified closed system (Tsai et al., 2008) at $1730 \mathrm{~h}-2200 \mathrm{~h}$ each day. We measured the $V_{\mathrm{O} 2}$ of fasting pit vipers in both groups for five days (day 1 -day 5 before feeding), the $V_{\mathrm{O} 2}$ of feeding vipers in group I at one-day (day 1-day 14) or two-day intervals (day 16day 36), and the $V_{\mathrm{O} 2}$ of feeding vipers in group II at half-day (day 0.5 -day 3.0) or one-day intervals (day 4-day 11). The respirometry chambers (volume $=875 \mathrm{~mL}$ ) were constructed with an in-current and ex-current air port, each attached to a three-way stopcock. Each snake was kept in its original container, unless during $V_{\mathrm{O} 2}$ measurements, they were transferred to individual respirometry chambers (black and opaque) and ventilated for $90 \mathrm{~min}$ to attain quiescence. Then, the chamber was connected with a column of desiccant (Drierite) and a gas analyzer in sequence. The gas flow rate was set at $1.2-2 \mathrm{~L} / \mathrm{min}$. The initial $\mathrm{O}_{2}$ concentration in the chamber was recorded as soon as the value becomes stable. Then, the chamber was sealed for $150 \mathrm{~min}$ and $90 \mathrm{~min}$ in groups I and II, respectively, after which the chamber was reconnected with the respirometer. The gas flowing through the $\mathrm{O}_{2}$ analyzer was directed to the chamber to make a closed circuit and final $\mathrm{O}_{2}$ concentration in the chamber was recorded. In most cases, final oxygen concentration did not decline below $19 \%$. Two samplings of the empty chamber per day provided a baseline measurement to compensate calculations for any drift in the $\mathrm{O}_{2}$ sensors. We measured $V_{\mathrm{O} 2}(\mathrm{~mL} / \mathrm{h})$ using the following formula: $V_{\mathrm{O} 2}=\left(\Delta F \times V_{\mathrm{a}}\right) /(\Delta t \times 100)$, where $\Delta F$ is the difference of initial and final oxygen concentration (\%) in the chamber with snake, $V_{\mathrm{a}}$ is the air volume $(\mathrm{mL})$ in the respirometer containing the snake (whose density was assumed as $1.0 \mathrm{~g} / \mathrm{mL}$ ), $\Delta t$ is time interval $(\mathrm{h}$ ) the chamber was sealed. The $V_{\mathrm{O} 2}$ measurements were corrected to STPD (standard temperature and pressure, dry) before analysis.

The mean of the lower three out of five measurements of $V_{\mathrm{O} 2}$ for each fasting snake was assigned as its standard metabolic rate (SMR). The $V_{\mathrm{O} 2}$ measurement during digestion of each individual was subjected to statistical and graphical analyses (SigmaPlot) for the variation of $V_{\mathrm{O} 2}$ as a function of post-feeding time. We characterized the postprandial $V_{\mathrm{O} 2}$ using one of the following two equations:

1) The log normal-four parameter equation (Andrade et al., 1997; Tsai et al., 2008):

$$
V_{\mathrm{O} 2}=y_{0}+a^{-0.5\left[\ln \left(x / x_{0}\right) / b\right]^{2}}
$$

2) The Weibull-five parameter equation (SPSS Inc., 2002):

$$
V_{02}=y_{0}+a \times k^{-k} \times\left(\left(\left(x-x_{0}\right) / b+k^{1 / c}\right)^{c-1}\right)^{-\left(\left(x-x_{0}\right) / b+k^{1 / c}\right)^{c}}+k
$$

Where $k=(c-1) / c, x=$ time of post-feeding (in days), and $x_{0}, y_{0}, a, b$ and $c$ are constants describing the rate of $V_{\mathrm{O} 2}$ change respect to time. For each viper, we chose the equations which gave larger adjusted determination coefficients $\left(r_{\mathrm{a}}^{2}\right.$; all $\left.r_{\mathrm{a}}^{2}>0.9, P<0.001\right)$. Each generated equation allowed us to determine the time of reaching peak $V_{\mathrm{O} 2}$ and SDA duration, which was judged as the time it took for the lower confidence limit of the SDA curve to overlap the upper confidence limit of pre-feeding values (Bushnell et al., 1994; Andrade et al., 1997). We integrated the area under each curve to quantify the total amount of oxygen consumed during digestion (Jobling, 1981; Andrade et al., 1997). The total oxygen consumed (area under the curve) minus that consumed in SMR is the SDA.

\subsection{Statistics}

All analyses were performed with the JMP and SAS 9.1 (SAS Institute Inc., Cary, NC, USA) statistical software. We used the ShapiroWilk tests of normality and Levene's tests of variance homogeneity. To meet the parametric assumption, variables of time to peak $V_{\mathrm{O} 2}$, apparent digestive energy, and apparent assimilation energy in group I and SDA and final defecation time in group II were log-transformed. For group I, we used a repeated measures analysis of covariance (log mouse mass as a covariate) to investigate the effect of species and venom (repeated factor, nested within species) on SDA-associated factors and defecation time conducted with SAS PROC MIXED (Littell et al., 1996). Because the statistical analyses of ratio-based indices (ex., digestive efficiency) are inappropriate when the relationship among denominator and numerator is allomatric and spurious correlations will result (Beaupre and Dunham, 1995; Packard and Boardman, 1999), we investigated variables of apparent digestive energy and assimilation energy (but not apparent digestive efficiency and assimilation efficiency) with the repeated measures analyses of covariance mentioned above while the covariate was log mouse energy. For group II, we used a twofactor analysis of covariance (log mouse mass as a covariate) to test the effect of species and venom (not repeated factor) on SDA-associated factors and defecation time, conducted with SAS PROC GLM (SAS Institute, 1985). For both groups, the slope homogeneity assumption was tested for all variables and no significant violations were detected. A post-hoc comparison (Tukey HSD) test was applied to distinguish mean values that differed significantly. $P$-values lower than 0.05 were taken as statistically significant. Data are presented as means \pm SE.

\section{Results}

The effects of prey-envenomating on the shapes of the postprandial metabolic profile for both T. gracilis and T. s. stejnegeri at $14{ }^{\circ} \mathrm{C}$

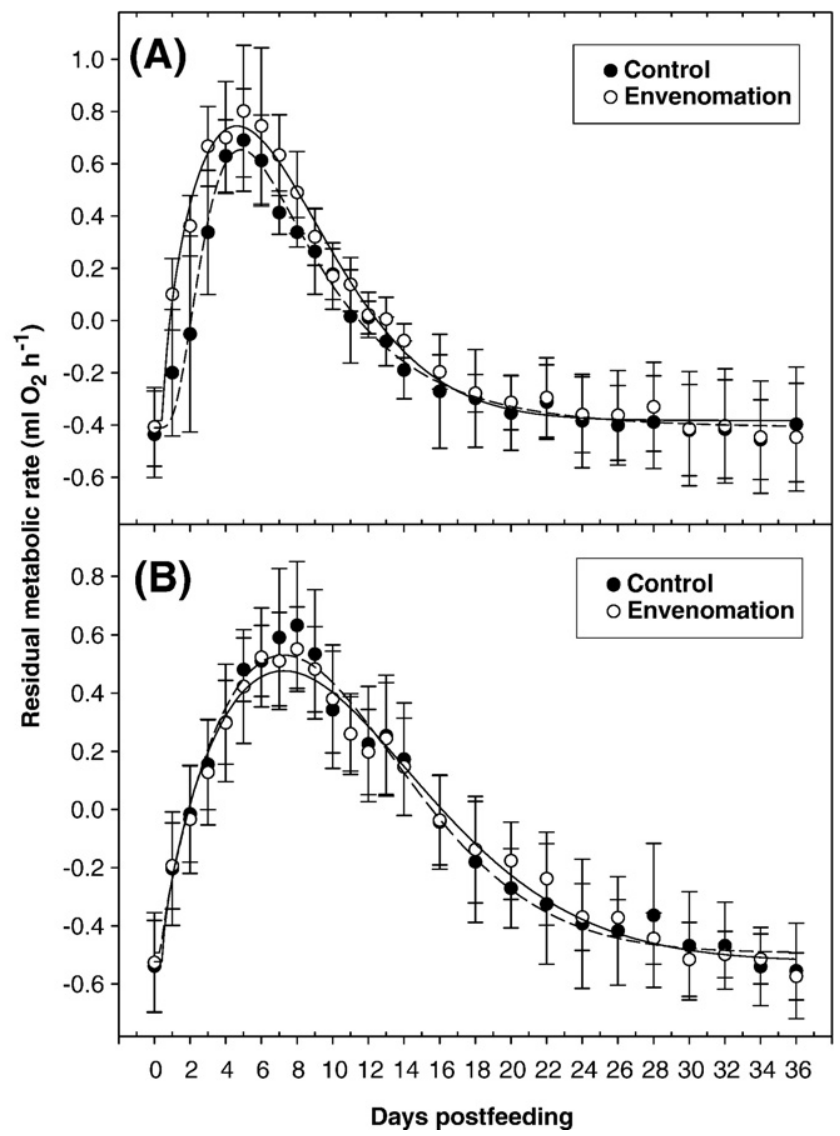

Fig. 1. Residual metabolic rate after adjustment for body mass of $T$. gracilis (A) and T. S. stejnegeri (B) prior to (day 0 ) and up to 36 days following ingestion of mouse meals equaling $10 \%$ of snake body mass at $14{ }^{\circ} \mathrm{C}$. Data were fitted through time (all $r_{\mathrm{a}}^{2}>0.97$ ) with an equation described in the text. Solid and dash lines represent the SDA profiles of snakes feeding on mice pre-injected snake venom and PBS, respectively. Vertical lines represent one SE of the means. 
and $24{ }^{\circ} \mathrm{C}$ were summarized in Figs. 1 and 2, respectively. By general linear regressions of metabolic rate vs. body mass, the residual metabolic rate after adjustment for body mass was shown in the figures, to remove the effects of body size (as in Beaupre and Zaidan, 2001; Zaidan, 2003). The raw data of variables measured for group I and group II snakes were shown in Tables 1 and 2. Results of statistical analysis were listed in Tables 3 and 4. There was no significant interaction of species and venom on all variables.

\subsection{Effects of envenomation on the digestion rate and SDA}

For group I (at $14{ }^{\circ} \mathrm{C}$ ), there was no significant effect of venom on time to peak $V_{\mathrm{O} 2}$ (least squared means of venom-treatment vs. control $=0.74 \pm 0.01$ vs. $0.73 \pm 0.02$ days; log-transformed), SDA duration ( $21.3 \pm 1.3$ vs. $20.1 \pm 1.1$ days), or final defecation time ( $28.7 \pm 2.1$ vs. $27.9 \pm 1.4$ days). The first defecation times of snakes feeding on envenomated mouse were significantly longer than controls $(15.8 \pm 0.8$ vs. $12.6 \pm 0.8$ days). For group II (at $24^{\circ} \mathrm{C}$ ), there was no significant effect of venom on all indicators of the timing of digestion, including the time to peak $V_{\mathrm{O} 2}$ (least squared means of venom-treatment vs. control $=1.2 \pm 0.08$ vs. $1.3 \pm 0.08$ days $)$, SDA duration $(6.3 \pm 0.4$ vs. $5.7 \pm$ 0.4 days), first defecation time ( $5.4 \pm 1.0$ vs. $6.7 \pm 1.0$ days), or final defecation time $(0.89 \pm 0.05$ vs. $0.84 \pm 0.05$ days; log-transformed).

For both groups I and II, there was no significant effect of venom on SDA values. The least squared mean of venom-treatment vs. control was $319.95 \pm 17.05$ vs. $307.80 \pm 14.92 \mathrm{~mL} \mathrm{O}_{2}$ at $14^{\circ} \mathrm{C}$ and $2.46 \pm 0.02$ vs. $2.42 \pm 0.02 \mathrm{~mL} \mathrm{O}_{2}$ (log-transformed) at $24{ }^{\circ} \mathrm{C}$.

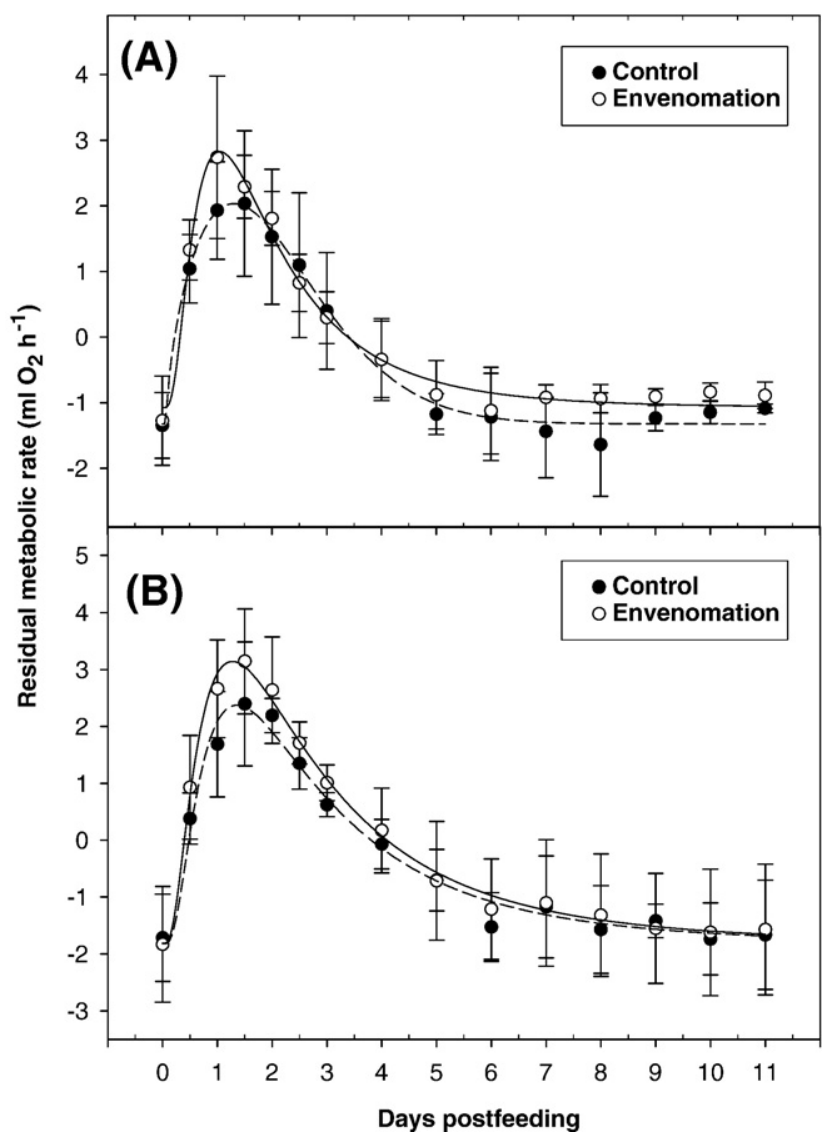

Fig. 2. Residual metabolic rate after adjustment for body mass of T. gracilis (A) and T. s. stejnegeri (B) prior to (day 0 ) and up to 11 days following ingestion of mouse meals equaling $10 \%$ of snake body mass at $24{ }^{\circ} \mathrm{C}$. Data were fitted through time (all $r_{\mathrm{a}}^{2}>0.97$ ) with an equation described in the text. Solid and dash lines represent the SDA profiles of snakes feeding on mice pre-injected snake venom and PBS, respectively. Vertical lines represent one SE of the means.
Table 1

Comparisons of SDA-associated factors, defecation time, and digestive efficiency in T. gracilis and T. s. stejnegeri, feeding on mice pre-injected snake venom or PBS (control) at $14{ }^{\circ} \mathrm{C}$

\begin{tabular}{|c|c|c|c|c|}
\hline & \multicolumn{2}{|l|}{ T. gracilis } & \multicolumn{2}{|l|}{ T. s. stejnegeri } \\
\hline & $\begin{array}{l}\text { Non-venom } \\
(n=7)\end{array}$ & $\begin{array}{l}\text { Venom } \\
(n=7)\end{array}$ & $\begin{array}{l}\text { Non-venom } \\
(n=8)\end{array}$ & $\begin{array}{l}\text { Venom } \\
(n=8)\end{array}$ \\
\hline Snake mass (g) & $\begin{array}{l}47.9 \pm 6.1 \\
(36.1-76.7)\end{array}$ & $\begin{array}{l}47.9 \pm 6.1 \\
(36.1-76.7)\end{array}$ & $\begin{array}{l}56.5 \pm 3.8 \\
(42.5-69.3)\end{array}$ & $\begin{array}{l}56.5 \pm 3.8 \\
(42.5-69.3)\end{array}$ \\
\hline Mouse mass (g) & $\begin{array}{l}4.8 \pm 0.6 \\
(3.5-7.6)\end{array}$ & $\begin{array}{l}4.8 \pm 0.6 \\
(3.6-7.6)\end{array}$ & $\begin{array}{l}5.6 \pm 0.4 \\
(4.2-6.9)\end{array}$ & $\begin{array}{l}5.7 \pm 0.4 \\
(4.5-7.0)\end{array}$ \\
\hline $\begin{array}{c}\text { Time to peak } \\
V_{\mathrm{O} 2} \text { (days) }\end{array}$ & $\begin{array}{l}4.2 \pm 0.3 \\
(3.1-4.9)\end{array}$ & $\begin{array}{l}4.3 \pm 0.1 \\
(3.9-4.6)\end{array}$ & $\begin{array}{l}6.9 \pm 0.4 \\
(4.8-7.9)\end{array}$ & $\begin{array}{l}7.1 \pm 0.3 \\
(5.9-7.9)\end{array}$ \\
\hline SDA duration (days) & $\begin{array}{l}18.9 \pm 2.0 \\
(12.5-26.5)\end{array}$ & $\begin{array}{l}19.4 \pm 1.7 \\
(13.0-27.0)\end{array}$ & $\begin{array}{l}21.2 \pm 1.0 \\
(16.0-26.0)\end{array}$ & $\begin{array}{l}23.3 \pm 2.2 \\
(15.0-35.0)\end{array}$ \\
\hline $\mathrm{SDA}\left(\mathrm{mL} \mathrm{O}_{2}\right)$ & $\begin{array}{l}260.6 \pm 28.0 \\
(188.0-363.7)\end{array}$ & $\begin{array}{l}282.0 \pm 34.8 \\
(178.8-470.7)\end{array}$ & $\begin{array}{l}348.0 \pm 41.1 \\
(200.7-522.2)\end{array}$ & $\begin{array}{l}356.2 \pm 48.9 \\
(207.8-552.0)\end{array}$ \\
\hline $\begin{array}{l}\text { First defecation } \\
\text { time (days) }\end{array}$ & $\begin{array}{l}10.1 \pm 1.4 \\
(6.0-16.0)\end{array}$ & $\begin{array}{l}13.4 \pm 1.1 \\
(8.5-17.5)\end{array}$ & $\begin{array}{l}15.1 \pm 0.8 \\
(13.0-18.5)\end{array}$ & $\begin{array}{l}18.1 \pm 1.2 \\
(14.5-24.0)\end{array}$ \\
\hline $\begin{array}{l}\text { Final defecation } \\
\text { time (days) }\end{array}$ & $\begin{array}{l}24.9 \pm 3.1 \\
(16.0-36.0)\end{array}$ & $\begin{array}{l}24.1 \pm 2.9 \\
(14.5-35.0)\end{array}$ & $\begin{array}{l}30.7 \pm 2.0 \\
(22.0-40.0)\end{array}$ & $\begin{array}{l}33.1 \pm 2.2 \\
(23.5-41.0)\end{array}$ \\
\hline $\begin{array}{l}\text { Apparent digestive } \\
\text { energy }(\mathrm{kJ})\end{array}$ & $\begin{array}{l}31.7 \pm 5.1 \\
(20.4-53.2)\end{array}$ & $\begin{array}{l}31.0 \pm 5.1 \\
(21.0-54.0)\end{array}$ & $\begin{array}{l}37.2 \pm 3.2 \\
(26.4-48.4)\end{array}$ & $\begin{array}{l}36.9 \pm 2.6 \\
(28.2-46.5)\end{array}$ \\
\hline $\begin{array}{l}\text { Apparent digestive } \\
\text { efficiency }\end{array}$ & $\begin{array}{l}0.92 \pm 0.02 \\
(0.83-0.96)\end{array}$ & $\begin{array}{l}0.89 \pm 0.01 \\
(0.83-0.92)\end{array}$ & $\begin{array}{l}0.86 \pm 0.02 \\
(0.81-0.93)\end{array}$ & $\begin{array}{l}0.85 \pm 0.02 \\
(0.73-0.92)\end{array}$ \\
\hline $\begin{array}{l}\text { Apparent assimilation } \\
\text { energy }(\mathrm{kJ})\end{array}$ & $\begin{array}{l}30.2 \pm 5.0 \\
(19.0-52.0)\end{array}$ & $\begin{array}{l}29.2 \pm 4.9 \\
(19.3-51.2)\end{array}$ & $\begin{array}{l}35.0 \pm 3.1 \\
(24.6-46.3)\end{array}$ & $\begin{array}{l}34.6 \pm 2.5 \\
(26.0-43.6)\end{array}$ \\
\hline $\begin{array}{l}\text { Apparent assimilation } \\
\text { efficiency }\end{array}$ & $\begin{array}{l}0.87 \pm 0.01 \\
(0.81-0.90)\end{array}$ & $\begin{array}{l}0.84 \pm 0.01 \\
(0.79-0.87)\end{array}$ & $\begin{array}{l}0.81 \pm 0.01 \\
(0.74-0.87)\end{array}$ & $\begin{array}{l}0.79 \pm 0.02 \\
(0.69-0.86)\end{array}$ \\
\hline
\end{tabular}

Note: Data (presented as means \pm SE) were measured from group I snakes, and the values shown in brackets are range of data. Variables are defined in the text.

\subsection{Effects of envenomation on digestive efficiency-associated variables}

For group I (at $14{ }^{\circ} \mathrm{C}$ ), after removing the effects of mouse energy, we found that there was no significant effect of venom on apparent digestive energy, while the assimilation energy of snakes feeding on envenomated mouse was smaller than controls. The least squared mean (log-transformed) of venom-treatment vs. control was $4.51 \pm$ 0.006 vs. $4.52 \pm 0.005 \mathrm{~J}$ for apparent digestive energy and was $4.48 \pm$ 0.007 vs. $4.50 \pm 0.005$ J for apparent assimilation energy. The raw data of apparent digestive efficiency and apparent assimilation efficiency were also shown in Table 1.

\subsection{Comparisons between the two pit vipers}

For group I (at $14{ }^{\circ} \mathrm{C}$ ), both the time to peak $V_{\mathrm{O} 2}$ and first defecation time of $T$. s. stejnegeri were longer than $T$. gracilis. The least squared

\section{Table 2}

Comparisons of SDA-associated factors and defecation time in T. gracilis and T. s. stejnegeri, feeding on mice pre-injected snake venom or PBS (control) at $24^{\circ} \mathrm{C}$

\begin{tabular}{|c|c|c|c|c|}
\hline & \multicolumn{2}{|l|}{ T. gracilis } & \multicolumn{2}{|l|}{ T. s. stejnegeri } \\
\hline & $\begin{array}{l}\text { Non-venom } \\
(n=4)\end{array}$ & $\begin{array}{l}\text { Venom } \\
(n=4)\end{array}$ & $\begin{array}{l}\text { Non-venom } \\
(n=4)\end{array}$ & $\begin{array}{l}\text { Venom } \\
(n=4)\end{array}$ \\
\hline Snake mass (g) & $\begin{array}{l}45.5 \pm 8.5 \\
(34.6-70.5)\end{array}$ & $\begin{array}{l}46.7 \pm 8.4 \\
(34.5-71.6)\end{array}$ & $\begin{array}{l}55.0 \pm 5.9 \\
(38.6-64.8)\end{array}$ & $\begin{array}{l}61.4 \pm 4.1 \\
(44.7-70.1)\end{array}$ \\
\hline Mouse mass (g) & $\begin{array}{l}4.5 \pm 0.8 \\
(3.5-7.1)\end{array}$ & $\begin{array}{l}4.7 \pm 0.8 \\
(3.5-7.2)\end{array}$ & $\begin{array}{l}5.5 \pm 0.6 \\
(3.9-6.5)\end{array}$ & $\begin{array}{l}6.1 \pm 0.4 \\
(4.5-7.0)\end{array}$ \\
\hline $\begin{array}{c}\text { Time to peak } \\
V_{\mathrm{O} 2} \text { (days) }\end{array}$ & $\begin{array}{l}1.2 \pm 0.1 \\
(0.9-1.6)\end{array}$ & $\begin{array}{l}1.1 \pm 0.1 \\
(0.9-1.2)\end{array}$ & $\begin{array}{l}1.5 \pm 0.2 \\
(1.2-1.9)\end{array}$ & $\begin{array}{l}1.3 \pm 0.1 \\
(1.0-1.4)\end{array}$ \\
\hline $\begin{array}{l}\text { SDA duration } \\
\text { (days) }\end{array}$ & $\begin{array}{l}5.6 \pm 0.7 \\
(4.0-7.5)\end{array}$ & $\begin{array}{l}5.7 \pm 0.4 \\
(4.5-7.5)\end{array}$ & $\begin{array}{l}6.02 \pm 0.4 \\
(5.5-7.0)\end{array}$ & $\begin{array}{l}6.9 \pm 0.5 \\
(5.5-7.5)\end{array}$ \\
\hline $\mathrm{SDA}\left(\mathrm{mL} \mathrm{O}_{2}\right)$ & $\begin{array}{l}235.7 \pm 53.1 \\
(167.7-393.2)\end{array}$ & $\begin{array}{l}241.0 \pm 33.8 \\
(175.3-330.0)\end{array}$ & $\begin{array}{l}300.4 \pm 45.8 \\
(218.7-414.7)\end{array}$ & $\begin{array}{l}393.7 \pm 52.8 \\
(294.9-498.9)\end{array}$ \\
\hline $\begin{array}{l}\text { First defecation } \\
\text { time (days) }\end{array}$ & $\begin{array}{l}6.4 \pm 1.6 \\
(3.5-10.5)\end{array}$ & $\begin{array}{l}4.5 \pm 1.1 \\
(3.0-7.5)\end{array}$ & $\begin{array}{l}6.8 \pm 1.3 \\
(4.5-9.0)\end{array}$ & $\begin{array}{l}6.5 \pm 1.4 \\
(3.0-9.5)\end{array}$ \\
\hline $\begin{array}{l}\text { Final defecation } \\
\text { time (days) }\end{array}$ & $\begin{array}{l}6.6 \pm 1.5 \\
(3.5-10.5)\end{array}$ & $\begin{array}{l}11.9 \pm 5.1 \\
(4.5-27.0)\end{array}$ & $\begin{array}{l}7.5 \pm 1.1 \\
(4.5-9.0)\end{array}$ & $\begin{array}{l}7.3 \pm 0.8 \\
(5.5-9.5)\end{array}$ \\
\hline
\end{tabular}

Note: Data (presented as means \pm SE) were measured from group II snakes, and the values shown in brackets are range of data. Variables are defined in the text. 
Table 3

Two-factor repeated measures analysis of covariance with mouse mass or mass energy as a covariate to investigate the effect of species and venom on digestion physiology in T. gracilis and T. s. stejnegeri at $14{ }^{\circ} \mathrm{C}$

\begin{tabular}{|c|c|c|c|}
\hline Variables & Source & $F_{1,13}$ & $P$ \\
\hline \multirow[t]{4}{*}{ Time to peak $V_{\mathrm{O} 2}$ (days) } & Species & 78.52 & $<0.0001$ \\
\hline & Venom & 0.34 & 0.5703 \\
\hline & Species by venom & 0.00 & 0.9493 \\
\hline & Mouse mass & 0.96 & 0.3446 \\
\hline \multirow[t]{4}{*}{ SDA duration (days) } & Species & 1.66 & 0.2203 \\
\hline & Venom & 0.53 & 0.4807 \\
\hline & Species by venom & 0.20 & 0.6655 \\
\hline & Mouse mass & 0.70 & 0.4180 \\
\hline \multirow[t]{4}{*}{$\mathrm{SDA}\left(\mathrm{mL} \mathrm{O}_{2}\right)$} & Species & 0.26 & 0.6207 \\
\hline & Venom & 0.50 & 0.4934 \\
\hline & Species by venom & 0.23 & 0.6378 \\
\hline & Mouse mass & 39.05 & $<0.0001$ \\
\hline \multirow[t]{4}{*}{ First defecation time (days) } & Species & 8.84 & 0.0108 \\
\hline & Venom & 13.24 & 0.0030 \\
\hline & Species by venom & 0.02 & 0.8865 \\
\hline & Mouse mass & 1.14 & 0.3059 \\
\hline \multirow[t]{4}{*}{ Final defecation time (days) } & Species & 2.80 & 0.118 \\
\hline & Venom & 0.11 & 0.7421 \\
\hline & Species by venom & 0.44 & 0.5170 \\
\hline & Mouse mass & 5.74 & 0.0324 \\
\hline \multirow[t]{4}{*}{ Apparent digestive energy } & Species & 0.53 & 0.4811 \\
\hline & Venom & 3.08 & 0.1030 \\
\hline & Species by venom & 0.28 & 0.6051 \\
\hline & Mouse energy & 817.93 & $<0.0001$ \\
\hline \multirow[t]{4}{*}{ Apparent assimilation energy } & Species & 1.39 & 0.2603 \\
\hline & Venom & 4.88 & 0.0457 \\
\hline & Species by venom & 0.61 & 0.4488 \\
\hline & Mouse energy & 783.52 & $<0.0001$ \\
\hline
\end{tabular}

Note: To meet the parametric assumption, variables of mouse mass, mouse energy, time to reach peak $V_{\mathrm{O} 2}$, apparent digestive energy, and apparent assimilation energy were log-transformed before analysis.

mean of the two species was $0.84 \pm 0.02$ vs. $0.63 \pm 0.02$ days (logtransformed) for time to peak $V_{\mathrm{O} 2}$ and was $16.3 \pm 0.9$ vs. $12.1 \pm 1.0$ days for first defecation time. Other variables between the two species were not significantly different. For group II (at $24^{\circ} \mathrm{C}$ ), no significantly different variables were seen between the two species.

\section{Discussion}

Viperid venom has been shown to contain higher activities or contents of hydrolytic enzymes, such as proteases, hyaluronidase, arginine esterase, 5'-nucleotidase, and collagenase, than elapid venom (Tu et al., 1965; Kocholaty et al., 1971; Simpson, 1975; Tan and Tan, 1988; Tan et al., 1989; Tan and Ponnudurai, 1990, 1991, 1992). Furthermore, adult viperids generally ingest heavy and bulky animals and might deliver a big amount of venom into their preys (chapter 4 in Greene, 1997). For above reasons, if some kinds of snake venom have evolved to facilitate digestion, they are most likely to be viperids' venom. However, our results revealed that pit viper venom did not contribute to prey digestion since digestion of envenomated prey was not improved at $14{ }^{\circ} \mathrm{C}$ or $24{ }^{\circ} \mathrm{C}$, in both T. gracilis and T. s. stejnegeri (Tables 3, 4 and Figs. 1, 2). The venom even caused longer first defecation time and lower assimilation energy at $14{ }^{\circ} \mathrm{C}$, which suggested that the venom might inhibit the digestion process and/or induce the feces-accumulating behavior which was frequently found in stout, heavy, terrestrial viperids and boids (Lillywhite et al., 2002). Above results did not support the hypotheses that the venom injected had a significant effect on prey digestion and that envenomation could improve the digestive performance more significantly at lower temperatures, especially in the cold-adapted T. gracilis. Our results were generally consistent with previous studies by McCue (2007) and Mendes and Abe (1999) that were conducted under higher temperature $\left(30{ }^{\circ} \mathrm{C}\right)$. These results challenged the popular long-standing paradigm that snake venom facilitates digestion. Besides, when comparing between the two pit vipers we studied, the time to reach the oxygen consumption peak $(7.0 \pm 0.2 \mathrm{~d})$ and the first defecation time (16.6 $\pm 0.8 \mathrm{~d})$ of $T$. s. stejnegeri were longer than those of T. gracilis ( $4.2 \pm$ 0.1 and $11.8 \pm 1.0 \mathrm{~d}$, respectively) at $14{ }^{\circ} \mathrm{C}$. This result was consistent with the phenomenon found in Tsai et al. (2008) that arboreal T. $s$. stejnegeri had a longer profile of postprandial metabolism than that of terrestrial snakes such as $T$. gracilis.

There were some flaws in the previous venom-digestion studies, which have been avoided in this study. First, Thomas and Pough (1979) used mice pre-injected with rattlesnake venom to evaluate their digestion in the stomach of non-venomous snakes, which may not be a suitable model for the actual conditions in venomous snakes. It has been shown that the digestive systems and physiology between python (non-venomous) and pit viper are different (Secor and Diamond, 2000). We used con-specific venom in this study to exclude above interfering factors. Second, Thomas and Pough (1979) injected $150 \mathrm{mg} \mathrm{C}$. atrox venom to a mouse. This dose is significantly higher than that delivered into a prey for most natural rattlesnake's bites, which are averaged to less than $50 \mathrm{mg}$ venom in general (see Table 1 in Hayes et al., 2002). The venom's contribution to digestion might not be as prominent as they reported if lower and naturaldoses of venom were injected into the mice. We did not over-dose the mice by venom, and the doses we injected were based on experimental measurements of the amount of venom injected per snakebite or closer to a real situation. Third, in the experiments carried out by McCue (2007), the venom was administered to dead mice and may not be able to distribute evenly throughout the prey. This did not happen in our study as the venom was injected while the mice were alive.

However, some issues might be argued against the conclusions of this study. First, it might be that improvement on digestion by venom could not be detected because the meal sizes were too small, i.e. $10 \%$ of the snake body weight in the present study and that of McCue (2007), or $30 \%$ in an earlier study (Mendes and Abe, 1999). As some pit vipers were able to ingest prey in $50 \%$ of their own body mass (Andrade et al., 1997), venom may only confer digestive advantages when exceptionally large meals with a low ratio of surface area to volume are consumed (McCue, 2007). Second, the digestion function may be too minor to be measured in the system-level. Most snake venom hydrolases (e.g. proteases and phospholipases) have very narrow specificities or low hydrolytic activities (Tsai, 2006). Venom hyaluronidase (Harrison et al., 2007) and proteolytic enzymes may help to break

\section{Table 4}

Two-factor analysis of covariance with mouse mass as a covariate to investigate the effect of species and venom on digestion physiology in T. gracilis and T. s. stejnegeri at $24{ }^{\circ} \mathrm{C}$

\begin{tabular}{llcr}
\hline Variables & Source & $F_{1,11}$ & \multicolumn{1}{l}{$P$} \\
\hline Time to peak $V_{\mathrm{O} 2}$ (days) & Species & 0.69 & 0.4245 \\
& Venom & 2.49 & 0.1428 \\
& Species by venom & 0.40 & 0.5410 \\
SDA duration (days) & Mouse mass & 2.54 & 0.1390 \\
& Species & 3.82 & 0.0765 \\
& Venom & 1.24 & 0.2884 \\
& Species by venom & 0.67 & 0.4308 \\
SDA $\left(\mathrm{mL} \mathrm{O}_{2}\right.$ ) & Mouse mass & 1.82 & 0.2044 \\
& Species & 1.63 & 0.2284 \\
& Venom & 1.33 & 0.2726 \\
First defecation time (days) & Species by venom & 0.66 & 0.4334 \\
& Mouse mass & 41.11 & $<0.0001$ \\
& Species & 0.04 & 0.8411 \\
& Venom & 0.94 & 0.3527 \\
Final defecation time (days) & Species by venom & 0.24 & 0.6350 \\
& Mouse mass & 1.34 & 0.2713 \\
& Species & 3.71 & 0.0804 \\
& Venom & 0.39 & 0.5436 \\
& Species by venom & 2.48 & 0.1438 \\
& Mouse mass & 11.89 & 0.0054 \\
\hline
\end{tabular}

Note: To meet the parametric assumption, variables of mouse mass, SDA, and final defecation time were log-transformed before analysis. 
down prey tissues to certain degrees, but the effects were too small to be revealed in the physiological parameters we measured (gut passage rate, costs of digestion, and digestive efficiency). Third, it might be argued that force-feeding in this study somehow affected SDA measurement and results. However, such possibility should be minor because a previous study on $T$. s. stejnegeri showed non-significant effects of force-fed procedure on SDA-associated factors, gut passage time, or digestive efficiency (Tsai et al., 2008).

It has been reported that the sea snakes, Emydocephalus annulatus and Aipysurus eydouxii, both evolving to become obligate fish-egg eaters, have an accompanying loss of fangs and greatly atrophied venom glands, as well as reduced venom lethal potencies by $40-100$ fold. A mutation and inactivation of the $A$. eydouxii neurotoxin gene was found to be the major adaptation strategy (Li et al., 2005a), and its venom phospholipases are of low catalytic power (Li et al., 2005b). Although, roles of the venom phospholipases to digest the egg diet has not been addressed, these findings also support that evolution of venom is directed to immobilize preys rather than to help their digestion. The relative importance of venom on predatory, defensive, and/or digestive functions needs further clarification.

\section{Acknowledgments}

We thank C.-F. Lin, T.-W. Shiau, R. Chin, and S. Wang for their assistances in laboratory and field. We are grateful to H.-J. Lee and colleagues for their helps with calorimetry measurements. Assistance by Y. Hsu and S.-P. Huang in statistical analyses is highly appreciated. Special thanks go to M.-Y. Liau and C.-K. Chen at Center of Preventive Medicine, Taiwan, for providing the anti-venom of T. s. stejnegeri.

\section{References}

Aird, S.D., 2002. Ophidian envenomation strategies and the role of purines. Toxicon 40 , 335-393.

Andrade, D.V., Cruz-Neto, A.P., Abe, A.S., 1997. Meal size and specific dynamic action in the rattlesnake Crotalus durissus (Serpents: Viperidae). Herpetologica 53, 485-493.

Beaupre, S.J., Dunham, A.E., 1995. A comparison of ration-based and covariance analyses of a nutritional data set. Funct. Ecol. 9, 876-880.

Bedford, G.S., Christian, K.A., 2000. Digestive efficiency in some Australian pythons. Copeia 2000, 829-834

Beaupre, S.J., Zaidan, F., 2001. Scaling of $\mathrm{CO}_{2}$ production in the timber rattlesnake (Crotalus horridus), with comments on cost of growth in neonates and comparative patterns. Physiol. Biochem. Zool. 74, 757-768.

Boback, S.M., Cox, C.L., Ott, B.D., Carmody, R., Wrangham, R.W., Secor, S.M., 2007. Cooking and grinding reduces the cost of meat digestion. Comp. Biochem. Physiol. A $148,651-656$.

Bradford, M.M., 1976. A rapid and sensitive method for the quantitation of microgram quantities of protein utilizing the principle of protein-dye binding. Anal. Biochem. 72, 248-254.

Bushnell, P.G., Steffensen, J.F., Schurmann, H., Jones, D.R., 1994. Exercise metabolism in two species of cod in arctic waters. Polar Biol. 14, 43-48.

Cox, C.L., Secor, S.M., 2007. Effects of meal size, clutch, and metabolism on the energy efficiencies of juvenile Burmese pythons, Python molurus. Comp. Biochem. Physiol. A $148,861-868$.

Daltry, J.C., Wüster, W., Thorpe, R.S., 1997. The role of ecology in determining venom variation in the Malayan pit viper. In: Thorpe, R.S., Wüster, W., Malhotra, A. (Eds.), Venomous Snakes: Ecology, Evolution and Snakebite. Symp. Zool. Soc. Lond. No. 70. Clarendon Press, Oxford, UK, pp. 155-172.

Deshimaru, M., Ogawa, T., Nakashima, K., Nobuhisa, I., Chijiwa, T., Shimohigashi, Y., Fukumaki, Y., Niwa, Y., Yamashina, I., Hattori, S., Ohno, M., 1996. Accelerated evolution of crotalinae snake venom gland serine proteases. FEBS Lett. 397, 83-88.

Fry, B.G., 2005. From genome to "venome": molecular origin and evolution of the snake venom proteome inferred from phylogenetic analysis of toxin sequences and related body proteins. Genome res. $15,403-420$.

Fry, B.G., Wuster, W., 2004. Assembling an arsenal: origin and evolution of the snake venom proteome inferred from phylogenetic analysis of toxin sequences. Mol. Biol. Evol. 21, 870-883.

Fry, B.G., Vidal, N., Norman, J.A., Vonk, F.J., Scheib, H., Ramjan, S.F., Kuruppu, S., Fung, K., Hedges, S.B., Richardson, M.K., Hodgson, W.C., Ignjatovic, V., Summerhayes, R., Kochva, E., 2006. Early evolution of the venom system in lizards and snakes. Nature 39, 584-588.

Gawęcki, J., Jeszka, J., 1979. The effect of the extent of hydrolysis in casein on its specific dynamic action in the rat. Br. J. Nutr. 40, 465-471.

Greene, H.W., 1997. Snakes: the Evolution of Mystery in Nature. University of California Press, Berkeley and Los Angeles, California.
Greenwald, T.E., Kanter, M.E., 1979. The effects of temperature and behavioral thermoregulation on digestive efficiency and rate in corn snake (Elaphe guttato guttata). Physiol. Zool. 52, 398-408.

Gutierrez, J.M., Rucavado, A., Escalante, T., Diaz, C., 2005. Hemorrhage induced by snake venom metalloproteinases: biochemical and biophysical mechanisms involved in microvessel damage. Toxicon 45, 997-1011.

Harrison, R.A., Ibison, F., Wilbraham, D., Wagstaff, S.C., 2007. Identification of cDNAs encoding viper venom hyaluronidases: cross-generic sequence conservation of fulllength and unusually short variant transcripts. Gene 392, 22-33.

Hayes, W.K., Kaiser, I.I., Duvall, D., 1992. The mass of venom expended by prairie rattlesnakes when feeding on rodent prey. In: Campbell, J.A., BrodieJr. Jr., E.D. (Eds.), Biology of the Pitvipers, pp. 383-388. Selva, Tyler, Texas.

Hayes, W.K., Herbert, S.S., Reeling, G.C., Gennaro, J.F., 2002. Factors that influence venom expenditure by viperids and other snake species during predatory and defensive contexts. In: Schuett, G.W., Höggren, M., Douglas, M.E., Greene, H.W. (Eds.), Biology of the Vipers. Eagle Mountain Publishing, Utah, pp. 207-234.

Huang, S.-M., Huang, S.-P., Chen, Y.-H., Tu, M.-C., 2007. Thermal tolerance and altitudina distribution of three Trimeresurus snakes (Viperidae: Crotalinae) in Taiwan. Zool. Stud. 46, 592-599.

Jobling, M., 1981. The influences of feeding on the metabolic rate of fishes: a short review. J. Fish Biol. 18, 385-400.

Kini, R.M., 2003. Excitement ahead: structure, function and mechanism of snake venom phospholipase A2 enzymes. Toxicon 42, 827-840.

Kocholaty, W.F., Ledford, E.B., Daly, J.G., Billings, T.A., 1971. Toxicity and some enzymatic properties and activities in the venoms of Crotalidae, Elapidae and Viperidae. Toxicon 9, 131.

Li, M., Fry, B.G., Kini, R.M., 2005a. Eggs-only diet: its implications for the toxin profile changes and ecology of the marbled sea snake (Aipysurus eydouxii). J. Mol. Evol. 60, 81-89.

Li, M., Fry, B.G., Kini, R.M., 2005b. Putting the brakes on snake venom evolution: the unique molecular evolutionary patterns of Aipysurus eydouxii (marbled sea snake) phospholipase A2 toxins. Mol. Biol. Evol. 22, 934-941.

Liau, M.Y., Huang, R.J., 1997. Toxoids and antivenoms of venomous snakes in Taiwan. J. Toxicol. 16, 163-175.

Lillywhite, H.B., de Delva, P., Noonan, B.P., 2002. Patterns of gut passage time and the chronic retention of fecal mass in viperid snakes. In: Schuett, G.W., Höggren, M. Douglas, M.E., Greene, H.W. (Eds.), Biology of the Vipers. Eagle Mountain Publishing, Utah, pp. 497-506.

Littell, R.C., Milliken, G.A., Stroup, W.W., Wolfinger, R.D., 1996. SAS System for Mixed Models. SAS Institute, Cary, North Carolina.

Lue, K.Y., Tu, M.C., Hsiang, K.S., 1999. A Field Guide to Amphibians and Reptiles of Taiwan. S.W.A.N. press, Taipei, Taiwan.

McConnachie, S., Alexander, G.J., 2004. The effect of temperature on digestive and assimilation efficiency, gut passage time and appetite in an ambush foraging lizard Cordylus melanotus melanotus. J. Comp. Physiol. B 174, 99-105.

McCue, M.D., 2007. Prey envenomation does not improve digestive performance in western diamondback rattlesnakes (Crotalus atrox). J. Exp. Zool. A 307, 568-577.

McCue, M.D., Lillywhite, H.B., 2002. Oxygen consumption and the energetics of islanddwelling Florida cottonmouth snakes. Physiol. Biochem. Zool. 75, 165-178.

Mendes, M.C., Abe, A.S., 1999. Specific dynamic action (SDA) in Crotalus durissus: does venom have any effect? Comp. Biochem. Physiol. A 124, S139.

Nicholson, J., Mirtschin, P., Madaras, F., Venning, M., Kokkinn, M., 2006. Digestive properties of the venom of the Australian Coastal Taipan, Oxyuranus scutellatus (Peters, 1867). Toxicon 48, 422-428.

Packard, G.C., Boardman, T.J., 1999. The use of percentages and size-specific indices to normalize physiological data for variation in body size: wasted time, wasted effort? Comp. Biochem. Physiol. A 122, 37-44.

SAS Institute, 1985. SAS User's Guide, Statistics, 5th ed. Cary, North Carolina.

Secor, S.M., 2003. Gastric function and its contribution to the postprandial metabolic response of the Burmese python Python molurus. J. Exp. Biol. 206, 1621-1630.

Secor, S.M., Diamond, J.M., 2000. Evolution of regulatory responses to feeding in snakes. Physiol. Biochem. Zool. 73, 123-141.

Simpson, J.W., 1975. Distribution of collagenolytic enzyme activity among snake venoms. Comp. Biochem. Physiol. B 51, 425-438.

SPSS Inc., 2002. SigmaPlot ${ }^{\circledR} 8.0$ Programming Guide. Chicago, Illinois.

Tan, N.-H., Tan, C.-S., 1988. A comparative study of cobra (Naja) venom enzymes. Comp. Biochem. Physiol. B 90, 745-750.

Tan, N.-H., Ponnudurai, G., 1990. A comparative study of the biological properties of venoms from snakes of the genus Vipera (true adders). Comp. Biochem. Physiol. B 96, 683-688.

Tan, N.-H., Ponnudurai, G., 1991. A comparative study of the biological activities of rattlesnake (genera Crotalus and Sistrurus) venoms. Comp. Biochem. Physiol. C 98 , 455-461.

Tan, N.-H., Ponnudurai, G., 1992. A comparative study of the biological properties of venoms of some old world vipers (subfamily Viperinae). Int. J. Biochem. 24, 331-336.

Tan, N.-H., Armugam, A., Tan, C.-S., 1989. A comparative study of the enzymatic and toxic properties of venoms of the Asian lance-headed pit viper (genus Tirmeresurus). Comp. Biochem. Physiol. B 93, 757-762.

Thomas, R.G., Pough, F.H., 1979. The effect of rattlesnake venom on digestion of prey Toxicon 17, 221-228.

Tsai, I.H., 2006. Evolutionary reduction of enzymatic activities of snake venom phospholipases A2. Toxin Rev. 26, 123-142.

Tsai, I.H., Wang, Y.M., Chiang, C.Y., Chen, Y.L., Huang, R.J., 2000. Purification, cloning and sequence analyses for pro-metalloprotease-disintegrin variants from Deinagistrodon acutus venom and sub-classification of the small venom metalloproteases. Eur. J. Biochem. 267, 1359-1367. 
Tsai, S.H., Chen, L., Chen, Y.C., Wang, Y.M., Tsai, I.H., 2007. Binding of a venom Lys49 phospholipase A2 to LPS and suppression of its effects on mouse macrophages. Toxicon 50, 914-922.

Tsai, T.-S., Lee, H.-J., Tu, M.-C., 2008. Specific dynamic action, apparent assimilation efficiency, and digestive rate in an arboreal pit viper, Trimeresurus stejnegeri stejnegeri. Can. J. Zool. 86, 1139-1151.

Tu, A.T., James, G.P., Chua, A., 1965. Some biochemical evidence in support of the classification of venomous snakes. Toxicon 3, 5-8.
Valerio, A.A., Corradini, A.C., Panunto, P.C., Mello, S.M., Hyslop, S., 2002. Purification and characterization of a phosphodiesterase from Bothrops alternatus snake venom. J. Protein Chem. 21, 495-503.

Wang, Y.M., Wang, S.R., Tsai, I.H., 2001. Serine protease isoforms of Deinagkistrodon acutus venom: cloning, sequencing and phylogenetic analysis. Biochem. J. 354, 161-168.

Zaidan III, F., 2003. Variation in cottonmouth (Agkistrodon piscivorus leucostoma) resting metabolic rates. Comp. Biochem. Physiol. A 134, 511-523. 